OPEN ACCESS

International Journal of Advanced Economics

P-ISSN: 2707-2134, E-ISSN: 2707-2142

Volume 3, Issue 3, P.No.72-79, July 2021

DOI: 10.51594/ijae.v3i3.238

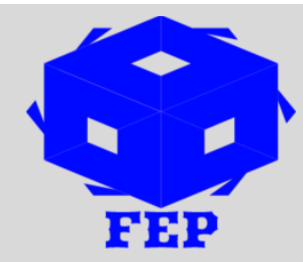

Fair East Publishers

Journal Homepage: www.fepbl.com/index.php/ijae

\title{
CO-INTEGRATION AND ERROR CORRECTION MODELING OF AGRICULTURAL OUTPUT: THE CASE OF CASSAVA IN ONDO STATE, NIGERIA
}

\author{
Adeyose Emmanuel Akinbola ${ }^{1}$ \\ ${ }^{1}$ Department of Agricultural Economics, Faculty of Agriculture, Adekunle Ajasin University, \\ Akungba-Akoko, Nigeria
}

*Corresponding Author: Adeyose Emmanuel Akinbola

Corresponding Author Email:

Article Received: 20-06-20

Accepted: 10-07-21

Published: 23-07-21

Licensing Details: The author retains the right to this article. The article is distributed under the terms of the Creative Commons Attribution-Noncommercial 4.0 License (http://www.creativecommons.org/licences/by-nc/4.0/) which permits non-commercial use, reproduction, and distribution of the work without further permission provided the original work is attributed as specified on the Journal open access page.

\begin{abstract}
Cassava is an important food crop in Nigeria providing households food security and income. Cassava production has received government and stakeholders' intervention dating back to the 1970s. Nevertheless, increased and sustainable production of the crop is under threat by exogenous factors of climate change and variability. This study investigates this concern by assessing the effects of climate change on cassava output in Ondo state, Nigerian using Cointegration and Error-Correction Modelling (ECM). Time series (1971-2010) data were sourced from the Central Bank of Nigeria (CBN), National Bureau of Statistics (NBS) Abuja, Nigerian Meteorological Agency Oshodi, Lagos. The results of the Augmented Dickey-Fuller (ADF) test revealed that all variables (cassava yield and climate variables; rainfall, temperature, and relative humidity) all have unit root problems (non-stationary) but become stationary after the first difference 1(1). The results confirmed a long-run equilibrium relationship between all identified variables as the absolute values of the variables are greater than their critical values at a 5\% level of significance for both trace statistics and maximaleigen values. The ECM result shows that rainfall exerts a positive effect, while temperature and relative humidity exert negative effects on cassava production. This indicates the sensitivity of cassava to climate change in the study area. Thus, increased and sustained production of cassava for household's food security income would be attainable by designing programmes and policies geared toward reducing the effect of climate change.
\end{abstract}


Keywords: Co-integration, Error-Correction Modeling, Cassava Output, Climate Variability, Nigeria.

\section{INTRODUCTION}

It is beyond dispute that agricultural production is the major preoccupation of Nigerian people; it is a reliable source of power for the industrial and economic development of the nation. Not until the discovery and export of crude petroleum oil in the 1970's Nigeria was a large exporter of agricultural produce and products. But this development has nose-dived over time due to the myriads of factors such as neglect as a result of rural-urban migration, low technological input, and unfavourable climatic conditions among others.

The Cassava crop is widely cultivated in Nigeria. Increased production of the crop in a sustainable manner can act as a boost to improve well-being and livelihood and households. Cassava ranks highly as a major staple food crop particularly for the low-income earners and resource-poor farmers in the developing economies of sub-Saharan Africa, (Stephen, 2017). Interestingly, Nigeria is currently the largest producer of cassava in the world with an annual output of over 34 million tonnes of tuberous roots (Ndichu et al., 2015). Cassava production fits well into the farming systems of the smallholder farmers in Nigeria because it is available all year round, thus providing household food and income. Cassava crop is not only for food crop but even more as a source of cash income for growers and marketers thereby, enhancing, food security and poverty alleviation (Sibhatu \& Qaim, 2017).

The Cassava crop has always played a vital role for its tuber roots which are rich in energy, containing mainly starch and soluble carbohydrates (Esiobu et al., 2015). Almost all the cassava produced is used for human consumption and a little for livestock feed and industrial purposes. The crop is available all year round, more tolerant of low fertility, and more resistant to drought, pest and diseases. Its roots are storable in the ground for months after they mature. Cassava production has the potential in alleviating food crisis and poverty, however, IITA (2011) asserts that cassava production in Africa is currently below average. Despite the rapid growth in cassava production, the cassava sub-sector in Nigeria is still constrained several factors, namely pest and diseases, agronomic problems, inconsistent policy measures, poor market access, inefficient extension delivery, and adequate access to improved processing technology (Ndichu et al., 2015). In addition to these limitations is the factor of climate change. Besides a series of non-climate related factors, the vulnerability of smallholder and subsistence farmers is greatly influenced by changes in climate (D'Odorico et al., 2013). A large percentage of the African population will enter poverty as short-term changes in climate will increase the stress on food production (Ahmed et al., 2011).

Climate variables of rainfall, temperature, humidity, and sunshine are the important elements of climate that influence crop production. In Nigeria, agricultural production relied heavily on climate, as rainfall is the major driver of crop yields. From the observation mentioned above, it is evident that climate will affect cassava output in Ondo state Nigeria. The state is known for high rainfall which is unpredictable in distribution and accompanied by storms and floods. The dry season (harmattan) is known for increased heat which poses danger to harvested and stored products. Hence it is germane to investigate the time series econometric study of the effect of climate change on cassava output using Ondo state, Nigeria as a case study. Cointegration and error-correction modeling are recent econometric techniques used by the researcher for macro-economic studies; instances are Klugman \& Loening (2007), Kareem et 
al., (2014), Adama \& Ohwofasa (2015), and Osabohien et al. (2018). This study is essential for policy decisions and planning for sustainable cassava production in Nigeria.

\section{Analytical Framework}

This study employs a co-integration and error-correction mechanism to investigate the effect of climate change on cassava output. The technique was used on the premise that there is the tendency that the time series data (1971-2010) of climate variables and cassava output to present a spurious or nonsense regression otherwise referred to as non-stationery. This could be due to the fluctuations in the data generation process. The time series have a unit root problem. To correct this problem, we adopt a long-run equilibrium model to test the cointegration and error correction analysis of climate variables and agricultural output (cassava) in Ondo state in Nigeria for the period spanning 1971-2010 (Kisaka-Lwayo, 2012) and Halagundegowda et al. (2021).

By this process, the relationship between climate variables and cassava output is measured under a dynamic state of affairs until the data series become stationary. Co-integration assumes that although the series under study may be individually non-stationary, a linear combination of them may have the trend term mutually canceled out so that it becomes stationary that is inter-dependence. Stationarity is achieved when the mean of variables fluctuates around a constant mean and the variance is finite, (Enders, 2015). If time-series are co-integrated, then they will be most efficiently represented by an error correction specification (Engle \& Granger, 2015). The error correction model (ECM) analyses the relationship under a dynamic state of affairs.

In recent times, co-integration and ECM have gained popularity in macro-economic research for reasons such as the simplicity and relevance in analyzing time-series data and the ability to ensure stationarity (Engle \& Granger, 2015). The technique has been used by researchers such as Klugman \& Loening (2007) to carry out the empirical investigation of short-run and longrun agricultural wage formation in Ghana. It was used by Kareem et al., (2014) to estimate the aggregate agricultural crop supply response in Nigeria. Kisaka-Lwayo (2012) applied cointegration to perform an induced innovation test of Iranian agriculture. In Nigeria Osabohien et al. (2018) used it to measure the effect of climate change on agricultural production.

\section{RESEARCH METHODOLOGY}

This research study was carried out in Ondo state, Nigeria. Nigeria is one of the sub-Saharan Africa (SSA) nations located in West Africa. Ondo state climate lies entirely in the tropics. The state has two distinct seasons, the rainy season (April-October) and the dry season (November-March) with slight variation from year to year. The climate and soils of Ondo state are highly favourable for growing cassava and other food crops. Farming is characterized by smallholdling with the use of simple farm implements. The study used time-series dates spanning 1971-2010 for climate variables (rainfall in $\mathrm{mm}$, the temperature in ${ }^{0} \mathrm{c}$, and relative humidity on $\%$ on average annual) and cassava yields in metric tons/hectare in Ondo state.

Data were sourced from Nigeria meteorological Agency, Central Bank of Nigeria, National Bureau of Statistics, and Ondo State Agricultural Development Project. Co-integration technique was used for the time-series data analysis. The first step in the co-integration analysis is to determine which variables are stationary and non-stationary in levels, and to achieve this, the Augmented Dickey and Fuller (ADF) test developed by Dickey and fuller, 1979 (Johansen, 1988). The null hypothesis of a unit root is rejected if the variable is stationary (Poramacom, 2014). If the series is non-stationary, that is, it has a unit root problem then an error correction modeling cannot be presented. Therefore, a non-stationary series 
require differencing to become stationary (Engle \& Granger, 2015). The number of times that is required to differentiate each variable in the series to make it stationary gives the order of integration of the series. If the series is differentiated once to turn it stationary, that means that the series is integrated of order 1 and is represented as 1(1) (Wawire, 2017)

\section{Test for Stationarity}

The ADF test for a unit root of stationarity is performed to the regression equation below,

$\mathrm{Ct}=\beta \mathrm{C}_{\mathrm{t}-1}+\mathrm{E}_{\mathrm{t}} \ldots \ldots \ldots \ldots$ Equation 1

Where $\mathrm{Ct}$ is the time series of the individual variables of climate and cassava yields.

$\mathrm{C}_{\mathrm{t}-1}$ is the lagged time series

$\beta$ is the coefficient on the lagged term

$E_{t}$ is the error term

In this instance $\beta 1$ is unity. $\mathrm{Ct}$, therefore, has a unit root (non-stationary), and has to be integrated of order 1(1) to become stationary. Hence, equation 1 was modified by subtracting $\mathrm{C}_{\mathrm{t}-1}$ from both sides of the equation to give,

$$
\mathrm{C}_{\mathrm{t}}-\mathrm{C}_{\mathrm{t}}-1=\beta_{1} \mathrm{C}_{\mathrm{t}-1}+\mathrm{E}_{\mathrm{t}}
$$

$=\left(\beta_{1}-1\right) C_{t-1}+E_{t}$

$=\Delta \mathrm{C}_{\mathrm{t}}=\mathrm{C}_{\mathrm{t}-1}+\mathrm{E}_{\mathrm{t}}$ Equation 2

Where $\Delta \mathrm{C}_{\mathrm{t}}$ is the first difference of the units of variable series under study become stationary, which is the existence of a unit root is rejected.

\section{Test for Co-Integration}

Test for co-integration was performed when stationarity of series was established (Johansen 1988, Engle \& Granger, 2015). The Johansen (1988) approach was adopted to test the presence of co-integrating vectors and estimation of long-run equilibrium of series. The Johansen (1998) procedure takes the advantage of involving a multivariate auto regression model that provides a method of estimating multiple co-integration relationships (Johansen \& Juselius, 1990). The co-integrating equation is presented as,

$\mathrm{C}_{\mathrm{t}}=\prod \mathrm{C}_{\mathrm{t}-1}+\prod_{2} \mathrm{C}_{\mathrm{t}-2}+\prod_{3} \mathrm{C}_{\mathrm{t}-3}+\Delta \mathrm{C}_{\mathrm{t}-3}+\mu+\mathrm{E}_{\mathrm{t}}$ equation 3 (Johansen, 1988)

Where each of the $\prod$ is an $\mathrm{n} x \mathrm{n}$ matrix of parameters.

$\mu$ is a constant term

Et (error term) are identically and independently distributed with zero means in this

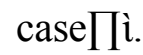
$>0$

$\mathrm{C}_{\mathrm{t}}$ is cassava productivity index 
$\mathrm{C}_{\mathrm{t}-1 \ldots \ldots \ldots . . . . .} \mathrm{C}_{\mathrm{t}-3}$ are climate variables of rainfall $(\mathrm{mm})$, temperature ${ }^{\circ} \mathrm{C}$, and relative humidity $(\%)$ average annual.

The maximum likelihood procedure for co-integration in line with Johansen and Juselius (1990) was utilized for analysis. This involves two testing procedures, firstly the maximal eigenvalue $(\Omega \max )$, the null hypotheses are at most $\boldsymbol{r}$ co-integrating vectors against the alternatives of $\boldsymbol{r}+\mathbf{1}$ co-integrating vectors. Secondly, the trace test ( $\Omega$ trace) where the null hypothesis that are $\boldsymbol{r}$ co-integrating vectors against the alternative hypothesis that there are $\boldsymbol{r}$ or more co-integrating vectors (Poramacom, 2014), Kwasi \& Kobina (2014), and Halagundegowda et al. (2021).

There should be at least one co-integrating vector for possible co-integration. The presence of a co-integrating relation forms the basis for error correction modeling (Engle \& Granger, 2015). The ECM can be specified as,

$\Delta \mathrm{C}_{\mathrm{t}}=\mu+\prod \mathrm{C}_{\mathrm{t}-\mathrm{k}}+£ \mathrm{er} \Delta \mathrm{C}_{\mathrm{t}-1}+\mathrm{Et}$ Equation 4

Where $C_{t}$ is an $n \times 1$ vector containing the series of interest (Climate variables and cassava yields series)

The estimate of rì measures the short-run adjustment to changes in $\mathrm{C}_{\mathrm{t}}$.

$\prod$, contains information on the long-run adjustment to changes in $C_{t}$ (Kisaka-Lwayo, 2012).

The estimate of rì measures the short-run adjustment to changes in $\mathrm{C}_{\mathrm{t}}$.

\section{RESULTS AND DISCUSSION}

\section{Test for Stationarity}

Table 1 shows the results of the analysis of the ADF unit roots test for stationarity and variable in the stochastic model. As can be observed from the table, it was established that all variables, cassava, rainfall, temperature, and relative humidity in the model are non-stationary at their levels, that they all contain units' roots. Therefore, the null hypothesis of the presence of a unit root cannot be rejected for all the variables in the model. Table 1 revealed that the absolute value of their ADF is greater than their critical values at levels for both $1 \%$ and $5 \%$ level of significance absolute value for cassava (1.3248), rainfall (0.3179) temperature (0.4043), and relative humidity (0.5974) is larger than the correspondence critical value ($1.9513)$ at $5 \%$ level of significance.

However, all series are stationary in the first difference. Therefore, each variable is integrated of order one 1 (1) as revealed in Table 1. The results rule out possible spurious correlations among the variables since all the variables are stationary of the same order 1 (1). Hence, the series can be tested for co-integration.

Table 1

Summary of ADF Unit Root Statistics for Cassava

\begin{tabular}{ccc}
\hline Variable & \multicolumn{2}{c}{ ADF Test Statistics } \\
\cline { 2 - 3 } & Level 1(0) & Level 1 (1) First difference \\
\cline { 2 - 3 } $\mathrm{C}(-1)$ & 1.3248 & -6.5502 \\
$\mathrm{R}(-1)$ & 0.3179 & -5.2205 \\
$\mathrm{~T}(-1)$ & 0.4043 & -11.3379 \\
$\mathrm{Rh}(-1)$ & 0.5974 & -11.3317 \\
\hline
\end{tabular}




\section{Johansen Co-Integration Test}

Table 2 shows the Johansen co-integration test results between cassava output and the identified climate variables including rainfall, temperature, and relative humidity. The results confirmed a long-run relationship between cassava yields and climate variables. The test in Table 2 indicates two co-integrating vectors at a 5\% significance level. The likelihood ratio test statistics of 66.46 and 31.61 are greater than their critical values of 47.86 and 29.80 respectively for trace tests. Also, for the maximal Eigen-value, the likelihood ratio test statistics 34.85 and 23.42 are greater than critical values 27.58 and 21.13 respectively. Hence, the null hypothesis of no co-integration was rejected in favour of the alternative for both the trace test and maximal Eigen-value at the conventional 5\% level of significance.

Thus, the cassava yields and climate variables (rainfall, temperature, and relative humidity) move together in the long run. This result is consistent with previous findings. This implies that the independent variables used in this model are the major determinants of cassava output in Ondo State, Nigeria. Kareem et al., (2014), Halagundegowda et al. (2021), and Osabohien et al. (2018) found that climatic favours particularly rainfall are important determinants of agricultural crop output in Nigeria.

Table 2

The Johansen Co-Integration Test

\begin{tabular}{ccccc}
\hline Null Hypothesis & Trace Statistics & 95\% Critical Value & Maxima-Eigen Value & 95\% Critical Value \\
\hline $\mathrm{r}=0$ & $66.46^{*}$ & 47.86 & $34.85^{*}$ & 27.58 \\
$\mathrm{r}=1$ & $31.61^{*}$ & 29.80 & $23.42^{*}$ & 21.13 \\
$\mathrm{r}=2$ & $8.19^{*}$ & 15.49 & $8.05^{*}$ & 14.26 \\
$\mathrm{r}=3$ & $0.14^{*}$ & 3.84 & $0.14^{*}$ & 3.84 \\
\hline \multicolumn{5}{c}{ Significant at 5\% level }
\end{tabular}

\section{Error Correction Model for Cassava}

Since the result of Johansen, likelihood test confirmed the existence of co-integrating, vectors among the variables in the model, then the Error correction Model (ECM) was performed on variables. Table 3 shows the ECM (1) carries a positive sign and is highly significant at a 5\% level of significance. This indicates a positive relationship between cassava output and the sets of climate variables, rainfall, temperature, and relative humidity. The significance of the ECM supports co-integration and suggests that there exists a long-run equilibrium state between cassava output and climate variables.

The coefficient of the error correction terms measures the speed at which cassava output adjusts to changes in climate to achieve long-run equilibrium. As shown in Table 3, the coefficients are small but significant at 5\% level of significance. For cassava farms, an increase of rainfall by 0.006 will increase cassava output by a unit while the coefficient of temperature and relative humidity carries a negative sign. This suggests that there is climate variability in the study area and the sensitivity of cassava output to climate change and variability. In the short run, cassava producers can respond to incentives geared toward an adjustment to climate change such as climate forecasting, improving cassava varieties and credit facilities. This confirms earlier findings such as Kareem et al., (2014) and Klugman and Loening (2007).

The rainfall coefficient is positive and significant at a 5\% level of significance. This implies that adequate rainfall is required for the increased production of cassava in Ondo state, Nigeria. This observation corroborates the findings of Adama \& Ohwofasa (2015). The negative signs of temperature and relative humidity show that there is a shortfall in cassava 
production due to climate variability such as heat stress. An adaptation strategy is suggested to cushion the effect of climate change. Gaining access to improve and heat-tolerant varieties, agro-chemicals, and credit facilities will enhance farmers' resilience to climate change. Thus, increased and sustainable cassava production would be attainable in Ondo State Nigeria.

Table 3

\begin{tabular}{|c|c|c|}
\hline Variable & coefficient & t-value \\
\hline ECM $-\mathrm{t}$ & 0.0912 & -0.6620 \\
\hline Rainfall $(-1)$ & 0.0063 & 0.3391 \\
\hline Temperature (-1) & -0.5654 & -0.5961 \\
\hline Relative Humidity- $(-1)$ & -0.2638 & -1.4124 \\
\hline Constant & -3.6417 & -0.5554 \\
\hline Adj R-Squared & -0.0741 & \\
\hline F- statistics & 0.6354 & \\
\hline
\end{tabular}

\section{CONCLUSION AND POLICY IMPLICATIONS}

The study estimates cassava output in Ondo state, Nigeria and climate variables for the period 1971-2010 using econometric techniques of co-integration and error correction model. The specific objectives were to examine the short-run and long-run effects of climate variability on cassava output in Ondo State.

The results of the analysis confirmed a long-run equilibrium relationship between cassava output and climate variables of rainfall, temperature, and relative humidity. The absolute values of all the variables in the model were greater than their critical values at a 5\% level of significance for both trace and maximal eigen value test at a 5\% level of significance. This implies the high sensitivity of climate variables as important determinants of cassava production.

The result of the error correction model revealed that rainfall has been responding positively to cassava production in the short and long run. Hence, increased and even distribution of rainfall during the cropping season will enhance food production and security. Temperature and relative humidity, however, impact negatively on cassava production in the long run. Heat stress will impair tubing of crops and enhance tuber-root due to microbial activities in the soil. In the short run, cassava production can adjust to variability in climate elements.

From the findings of this study, the conclusion that could be drawn is that rainfall, temperature and relative humidity are the important climatic variables that affect cassava output in Ondo State and Nigeria. Thus, increased and sustainable production of cassava would be achieved by long-term policy measures that could spur the adaptation of farmers to climate change and variability. Such measures include climate forecasting mechanism, development, and distribution of improved/tolerant varieties of cassava cuttings to farmers, improved processing, and marketing system and access to credit facilities by cassava growers.

\section{References}

Adama, I. J., \& Ohwofasa, B. O. (2015). Determinants of Agricultural Export Earnings in Nigeria, 1980-2011 Determinants of Agricultural Export Earnings in Nigeria, 19802011. International Journal of innovative research and Development, 4(8), 318-326.

Ahmed, S. A., Diffenbaugh, N. S., Hertel, T. W., Lobell, D. B., Ramankutty, N., Rios, A. R., \& Rowhani, P. (2011). Climate volatility and poverty vulnerability in Tanzania. Global Environmental Change, 21(1), 46-55. 
D’Odorico, P., Bhattachan, A., Davis, K. F., Ravi, S., \& Runyan, C. W. (2013). Global desertification: drivers and feedbacks. Advances in Water Resources, 51, 326-344.

Enders, W. (2015). Applied econometric time series $\left(4^{\text {th }}\right.$ Edn. $)$.

Engle, R., \& Granger, C. (2015). Co-integration and error correction: Representation, estimation, and testing. Applied Econometrics, 39(3), 106-135.

Esiobu, N. S., Nkete, G. A., Ejiogu, A. O., \& Onubuogu, G. C. (2015). Analysis of use of ajo in financing cassava production in Aniocha north local government of Delta State, Nigeria. Journal of Poverty, Investment and Development, 8(20), 1-21.

Halagundegowda, G. R., Kumaresan, P., Kantharaju, B. M., \& Pallavi, J. (2021). Modelling of price transmission: Evidences from Indian silk market.

IITA (2011): International institute of Tropical Agriculture, Ibadan Oyo state, Nigeria. Annual report on cassava production.

Johansen, S. (1988). A statistical analysis of co-integration vectors. Journal of Economic Dynamics and Control, 12(2-3), 231-254.

Johansen, S., \& Juselius, K. (1990): Maximum likehood and inference on co-integration with application to the demand for money. Oxford Bulletin of Economics and Statistics, 52, 169-210.

Kareem, R. O., Ayinde, I. A., Bakare, H. A., \& Bashir, N. O. (2014). Determinants of Aggregate Agricultural Supply Response in Nigeria (1960-2010). Nigerian Journal of Agricultural Economics, 4(2066-2018-921), 44-57.

Kisaka-Lwayo, M. (2012). Risk preferences and consumption decisions in organic production: the case of KwaZulu-Natal and Eastern Cape Provinces of South Africa (Doctoral dissertation, University of Fort Hare).

Klugman, J., \& Loening, J. (2007). Welfare impacts of food price inflation in Ethiopia.

Kwasi, B. R., \& Kobina, B. J. (2014). Cassava markets integration analysis in the central region of Ghana. Indian Journal of Economics and Development, 10(4), 319-329.

Ndichu, J., Blohmke, J., Kemp, R., Adeoti, J., \& Obayelu, A. E. (2015). The adoption of energy efficiency measures by firms in Africa: case studies of cassava processing in Nigeria and maize milling in Kenya. Innovation and Development, 5(2), 189-206.

Osabohien, R., Osabuohien, E., \& Urhie, E. (2018). Food security, institutional framework and technology: Examining the nexus in Nigeria using ARDL approach. Current Nutrition \& Food Science, 14(2), 154-163.

Poramacom, N. (2014). Rice production, prices and related policy in Thailand. International Journal of Business and Social Science, 5(10).

Sibhatu, K. T., \& Qaim, M. (2017). Rural food security, subsistence agriculture, and seasonality. PloS One, 12(10), e0186406.

Stephen, K. O. (2017). Tropical root and tuber crops. Advances in New Crops Relieved 26th July.

Wawire, N. (2017). Determinants of value added tax revenue in Kenya. Journal of Economics Library, 4(3), 322-344. 